\title{
Implementing Electronic Courses Based on Moodle for Foreign Language Teaching at Russian Technical Universities
}

\author{
http://dx.doi.org/10.3991/ijet.v10i3.4501 \\ T. Yu. Aikina, O.V. Sumtsova, D. I. Pavlov \\ National Research Tomsk Polytechnic University, Tomsk, Russia
}

\begin{abstract}
The main purpose of this work is to consider the most efficient modern educational technologies applied in teaching foreign languages to students of higher educational institutions in the Russian Federation. Special emphasis is placed on blended learning as a pedagogical approach of high priority. It is necessary to note that informationcommunication environment plays a great role in the realization of blended learning since the organization of educational process is impossible without it. The authors of the paper give consideration to one of the most relevant educational platform Moodle. An electronic course based on Moodle developed for the first year students of Tomsk Polytechnic University within teaching the discipline "Foreign Language" is reviewed in this work. The authors come to the conclusion that electronic courses designed by means of the e-learning platform Moodle are ideally suitable for the efficient blended learning implementation.
\end{abstract}

Index terms-e-course, effective educational methods, elearning, foreign language of professional communication, Moodle, students of technical specialties

\section{INTRODUCTION}

At the present day one of the most important concerns for the Russian Federation is to become a respectable member of the world community. International interactions in terms of economic, political, social, cultural and scientific ties are developing quite fast. It is worthy to note that a higher education system plays an integral role in these processes. Graduates of leading higher educational institutions are supposed to be competitive and highly qualified specialists in their professional fields. This is particularly so with the students of technical engineering specialties as they have to keep abreast in scientific developments and become not only professional and competent subject matter experts but also they must be able to apply their knowledge in global engineering as a whole. Their skills and qualifications must meet international requirements for the foregoing purposes.

Without doubt, these tendencies are reflected in the methods of foreign languages (FL) teaching and absolutely new issues in the theory and practice of teaching have appeared. Disciplines "Foreign language" and "Foreign Language of Professional Communication" are crucial for modern engineering education nowadays. However, in spite of the great importance of the above mentioned disciplines, FL teachers constantly face challenges in the learning process organization. To begin with, it is necessary to confess that having entered an engineering univer- sity, most of the students of technical specialties demonstrate a low level of FL proficiency at the initial stage as well as not enough motivation to FL learning. Consequently, it will be difficult for such students to master not only FL but also all the other obligatory humanitarian subjects. The majority of future engineers possess the so called "mechanical intelligence" and, in contrast with the students of humanitarian specialties, they have not got a linguistic feeling. It is common knowledge that a lack of the linguistic feeling considerably complicates an effective FL mastering. That is why modern FL teachers use new effective educational methods and approaches in FL teaching to motivate their students.

\section{BACKGROUND}

Let us consider one of the most effective educational approaches to FL teaching at technical universities. Since the beginning of the XXI century the methods of FL teaching have changed a lot at most higher educational institutions of the Russian Federation.

Nowadays methodologists and teachers prefer using communication oriented concepts in FL teaching. Practical application of communicative approach proves that it provides FL mastering as the communication means, broadens the students' mind and teaches them to improve independently their abilities and skills in the future. The students learn how to intercommunicate and actively use the gained knowledge not only in everyday situations but also in the professional activity. All this contributes the efficient acquirement of the educational materials, quick and firm memorization.

However, in spite of all positive sides of the communication oriented approach, many graduates of technical universities do not master FL at a high level, as a result young specialists are not able to apply the gained knowledge in their professional field and compete in the world labor market. One of the causes of this challenge is concerned with the restricted number of academic hours designated for the discipline "Foreign Language" in the basic curriculum at the most technical higher schools in Russia. As a result, most of the students attend FL classes only twice a week, in other words they have four academic hours a week for FL learning. What is more, the students of technical specialties study FL only during the first and the second years of education. Beyond all doubt, it is impossible to master FL perfectly for such a short period of time. But this problem can be solved by means of blended learning. 


\section{BLENDED LEARNING IN FOREIGN LANGUAGE TEACHING}

FL teachers were among the pioneers in applying information technologies and blended learning in higher education. And their professional experience has already proved the efficiency of the approach.

Blended learning is usually determined as a combination of classroom training with training based on the application of up-to-date Internet resources which allow students and teachers to realize synergy. In other words, blended learning brings together online learning and traditional studies which take place according to the schedule. Learning is supposed to be blended provided that the learners spend from $30 \%$ to $79 \%$ of the study time mastering the discipline online. One more obligatory requirement of blended learning is three ways of delivery: different time/ different place (asynchronous), same time/ different place (synchronous) and same time/same place (traditional classroom). Consequently, blended learning includes both face-to face and distant learning simultaneously; in its turn it allows students and teachers to use the main benefits of these teaching methods.

It is necessary to mention that the relevant methodological support of the subject syllabus plays a vital role in the effective realization of blended learning. In the process of learning methodological support of the syllabus usually contains essential teaching materials and up-to-date information communication technologies. Information support of the educational activity often depends on the structure of the university in general, the learning process organization system and also on the information communication technologies the university applies in training. Tomsk Polytechnic University makes use of the e-learning platform Moodle as information communication environment.

\section{Practical APPliCATION OF MOODLE PLATFORM}

Moodle is based on the system that manages the educational process by means of the Internet technologies. Thank to this Web application teachers have the opportunities to design their own electronic courses (e-courses) and control the access to them. A wide range of instruments provided by the platform under discussion make ecourses multifunctional. The teachers have at their disposal such useful tools as data base, glossary, tests, forum, chat room, wiki, lectures and etc. One of the most significant instruments is a test system by means of which it is possible to form a bank of tests using the most wide spread task types, for instance Multiple Choice, Gaps Filling, True/False, Matching, Drag and Drop tasks. The tests are designed for a great variety of purposes: for self control and self assessment, placement and achievement tests, and students' independent work. A computer assisted system of assessment, active hyperlinks to the relevant outer Internet resources, the possibility for educators to look through the statistics (time consumed on the tests, average score, number of tries when completing the tests etc.) can be mentioned among the main advantages of Moodle.

It is essential to review the obligatory requirements worked out by the group of specialists having responsibility for the development of e-courses at TPU. The most significant requirements are the following:

1. e-course contains full information about its developer;
2. e-course presents a detailed description of the discipline;

3. each module of e-course includes a glossary containing about sixty elements or more;

4. learning outcomes must be determined for each module of e-course;

5. educational materials correspond up-to-date development levels of science and regulatory framework;

6. e-course includes visualization such as animation, illustrations, graphic objects etc.;

7. e-course offers relevant additional resources including open educational resources;

8. e-course contains tasks for students' independent work being assessed in electronic environment;

9. each activity offers instructions how to work with it; 10. e-course involves peer review and assessment.

All the above mentioned obligatory requirements must be observed when developing e-courses. Completed ecourses are always examined and analyzed by a special panel of experts and if the requirements are not observed, the e-course is dismissed for improving.

Now let us consider the particular e-course developed for the first year students of Institute of High Technology Physics (IHTP), Tomsk Polytechnic University and put to use in 2014. One hundred and six students were involved into the process of working with the e-course. Ninetyeight students (94\%) completed the e-course successfully; eight students $(6 \%)$ were not making progress and were subsequently sent down. The students were dealing with the e-course during the spring semester of the 20132014 academic year.

The course is called "English language for the first-year students of IHTP. Module 2" and consists of three units:

1. Travelling. The unit provides the students with the information about various means of transport and types of holidays. At the end of the e-course the students will be able:

- to check in at the airport,

- to make a reservation for a hotel room,

- to talk about advantages and disadvantages of different ways of travelling and types of holidays.

2. Environmental protection. The unit provides the students with the information about the most urgent environmental problems around the world. At the end of the e-course the students will be able:

- to talk about causes and consequences of the most urgent environmental problems all over the world,

- to talk about ecological problems of their regions,

- to talk about endangered animal species and ways of protecting animals from extinction,

- to talk about environmental protection.

3. Education. The unit provides the students with the information about higher education in Russia and English-speaking countries. At the end of the e-course the students will be able:

- to talk about higher education in Russia and English-speaking countries,

- to talk about National Research Tomsk Polytechnic University: university structure, scientific directions, social life, academic mobility, outstanding graduates and future prospects. 
SHORT PAPER

IMPLEMENTING ELECTRONiC COURSES BASED ON MOODLE FOR FoREIGN LANGUAGE TEACHING AT RUSSIAN TECHNI...

TABLE I.

A PART OF THE E-COURSE SYLLABUS

\begin{tabular}{|c|c|c|c|c|c|}
\hline № & Instructional Strategies/ Activities & $\begin{array}{l}\text { Points } \\
\text { max. }\end{array}$ & Delivery & Date & Group Index \\
\hline \multicolumn{6}{|c|}{ Unit 1 (Travelling) } \\
\hline 1 & $\begin{array}{l}\text { Teaching material review (grammar video lectures, work- } \\
\text { book on the subject "Travelling", additional resources) }\end{array}$ & & $\begin{array}{l}\text { Different Time/ Different Place } \\
\text { (Asynchronous) }\end{array}$ & $10.02 .2014-13.02 .2014$ & $\begin{array}{l}\text { the first-year } \\
\text { students }\end{array}$ \\
\hline 2 & $\begin{array}{l}\text { Watching the video "Three reasons on why travelling } \\
\text { abroad" and discussing the topic in the chat room. }\end{array}$ & 0,5 & $\begin{array}{l}\text { Same Time/ Different Place } \\
\text { (Synchronous) }\end{array}$ & 14.02 .2014 & $\begin{array}{l}\text { the first-year } \\
\text { students }\end{array}$ \\
\hline 3 & Completing online test "At the airport" & 0,5 & $\begin{array}{l}\text { Different Time / Different Place } \\
\text { (Asynchronous) }\end{array}$ & 17.02 .2014 & $\begin{array}{l}\text { the first-year } \\
\text { students }\end{array}$ \\
\hline 4 & $\begin{array}{l}\text { Completing online tests "Travel and holidays" and "Beach } \\
\text { holidays" }\end{array}$ & 1 & $\begin{array}{l}\text { Different Time / Different Place } \\
\text { (Asynchronous) }\end{array}$ & 18.02 .2014 & $\begin{array}{l}\text { the first-year } \\
\text { students }\end{array}$ \\
\hline 5 & $\begin{array}{l}\text { Panel discussion } \\
\text { (Means of transport: advantages and disadvantages) }\end{array}$ & 1 & $\begin{array}{l}\text { Same Time / Same Place } \\
\text { (Traditional classroom) }\end{array}$ & 21.02 .2014 & $\begin{array}{l}\text { the first-year } \\
\text { students }\end{array}$ \\
\hline 6 & $\begin{array}{l}\text { Writing assignment } \\
\text { (a personal letter on the subject "Popular holidays in } \\
\text { Russia"), uploading the letters into the forum for peer } \\
\text { review and assessment }\end{array}$ & 1 & $\begin{array}{l}\text { Different Time / Different Place } \\
\text { (Asynchronous) }\end{array}$ & 25.02 .2014 & $\begin{array}{l}\text { the first-year } \\
\text { students }\end{array}$ \\
\hline 7 & Online assessments \& testing (an achievement test) & 3 & $\begin{array}{l}\text { Different Time / Different Place } \\
\text { (Asynchronous) }\end{array}$ & $26.02 .2014-27.02 .2014$ & $\begin{array}{l}\text { the first-year } \\
\text { students }\end{array}$ \\
\hline 8 & $\begin{array}{l}\text { Summing-up: presenting the projects "My dream holi- } \\
\text { days" }\end{array}$ & 5 & $\begin{array}{l}\text { Same Time / Same Place } \\
\text { (Traditional classroom) }\end{array}$ & 28.02 .2015 & $\begin{array}{l}\text { the first-year } \\
\text { students }\end{array}$ \\
\hline & Total & 12 & & & \\
\hline \multicolumn{6}{|c|}{ Unit 2 (Environmental protection) } \\
\hline 9 & $\begin{array}{l}\text { Teaching material review (grammar video lectures, work- } \\
\text { book on the subject "Environmental issues and protec- } \\
\text { tion", additional resources) }\end{array}$ & & $\begin{array}{l}\text { Different Time / Different Place } \\
\text { (Asynchronous) }\end{array}$ & $03.03 .2014-05.03 .2014$ & $\begin{array}{l}\text { the first-year } \\
\text { students }\end{array}$ \\
\hline 10 & Completing online test "Nature and environment" & 0,5 & $\begin{array}{l}\text { Different Time / Different Place } \\
\text { (Asynchronous) }\end{array}$ & 06.03 .2014 & $\begin{array}{l}\text { the first-year } \\
\text { students }\end{array}$ \\
\hline 11 & $\begin{array}{l}\text { Watching a video "Global warming" and completing } \\
\text { online test }\end{array}$ & 0,5 & $\begin{array}{l}\text { Different Time / Different Place } \\
\text { (Asynchronous) }\end{array}$ & 11.03 .2014 & $\begin{array}{l}\text { the first-year } \\
\text { students }\end{array}$ \\
\hline 12 & $\begin{array}{l}\text { Watching a video "The most polluted place on Earth", } \\
\text { completing online test }\end{array}$ & 0,5 & $\begin{array}{l}\text { Different Time / Different Place } \\
\text { (Asynchronous) }\end{array}$ & 12.03 .2014 & $\begin{array}{l}\text { the first-year } \\
\text { students }\end{array}$ \\
\hline 13 & $\begin{array}{l}\text { Discussing the video "The most polluted place on Earth" } \\
\text { in the chat room }\end{array}$ & 0,5 & $\begin{array}{l}\text { Same Time/ Different Place } \\
\text { (Synchronous) }\end{array}$ & 14.03 .2014 & $\begin{array}{l}\text { the first-year } \\
\text { students }\end{array}$ \\
\hline 14 & $\begin{array}{l}\text { Panel discussion } \\
\text { (The most urgent ecological problems: causes and conse- } \\
\text { quences) }\end{array}$ & 1 & $\begin{array}{l}\text { Same Time / Same Place } \\
\text { (Traditional classroom) }\end{array}$ & 17.03 .2014 & $\begin{array}{l}\text { the first-year } \\
\text { students }\end{array}$ \\
\hline 15 & $\begin{array}{l}\text { Writing assignment } \\
\text { (a personal letter on the subject "The most urgent envi- } \\
\text { ronmental issues of my region"), uploading the letters in } \\
\text { the forum for peer review and assessment }\end{array}$ & 1 & $\begin{array}{l}\text { Different Time / Different Place } \\
\text { (Asynchronous) }\end{array}$ & 19.03.2014 & $\begin{array}{l}\text { the first-year } \\
\text { students }\end{array}$ \\
\hline 16 & Online assessments \& testing (an achievement test) & 3 & $\begin{array}{l}\text { Different Time / Different Place } \\
\text { (Asynchronous) }\end{array}$ & 21.03 .2014 & $\begin{array}{l}\text { the first-year } \\
\text { students }\end{array}$ \\
\hline 17 & $\begin{array}{l}\text { Summing-up: } \\
\text { a role play "Polluted city" }\end{array}$ & 5 & $\begin{array}{l}\text { Same Time / Same Place } \\
\text { (Traditional classroom) }\end{array}$ & 25.03 .2014 & $\begin{array}{l}\text { the first-year } \\
\text { students }\end{array}$ \\
\hline & Total & 12 & & & \\
\hline
\end{tabular}

After completing the given e-course the students are supposed to improve their reading, writing and listening skills and acquire knowledge which help them:

1. to apply language skills for the solution of communicative problems,

2. to acquire basic grammatical structures, typical for social communication,

3. to apply different reading skills effectively to a variety of text types,

4. to extract key information while listening dialogues and monologues in English,

5. to state the ideas logically in the situations of verbal and written social communication.

\section{CONCLUSIONS}

In this regard the following conclusions should be made:

1. The e-course under consideration comprises three ways of delivering: different time/different place (asynchronous), same time/different place (synchronous) and same time/same place (traditional classroom or face-to-face learning). Consequently, the e-course complies with the concepts of blended learning.

2. The e-course contains up-to-date educational materials which coincide with the basic syllabus of the discipline "Foreign Language" accredited by the Ministry of Higher Education of the Russian Federation. 
3. The e-course conforms fully to the obligatory requirements having been considered before.

4. There was the only challenge in the process of carrying out the tasks provided in the e-course: most of the students (about $76 \%$ ) had difficulties with peer review and assessment in the forums as the activity was relatively new for them and only twenty -five students (24\%) were able to assess personal letters uploaded into the forum by their peers. In general it is advisable to practice peer review and assessment in the traditional classroom before dealing with the activity in the forum of the e-course.

In conclusion it should be mentioned that the e-course under consideration is recommended for the first year students to complete in the spring semester of the 20142015 academic year as it complies with the concepts of blended learning being implemented at TPU.

The practice of applying blended learning as one on the most efficient educational technologies demonstrates that the model under review considerably expands the restricted number of academic hours for the discipline "FL" in the basic curriculum of technical universities. As a result, the students have much more opportunities for mastering and consolidating the learned material. Moreover, ecourse as an integral part of blended learning raises students' motivation to acquiring FL since most of the students find it fascinating and challenging to gain knowledge and improve their skills and competences by means of modern educational technologies.

\section{REFERENCES}

[1] Barybin A.V. Information technologies in professionally oriented foreign language teaching the students of technical specialties: $\mathrm{PhD}$ dissertation. Moscow, 2005, pp. 45-58.
[2] Galskova N.D., Gez N.I. (2006). Theory of learning foreign languages. Linguodidactics and methodology. Moscow, pp. 31-33.

[3] Selevko G.K. (2006). Encyclopedia of educational technologies. Vol. 2. Moscow, 816 p.

[4] Jacob Anna M. (2011). Benefits and Barriers to the Hybridization of Schools. Journal of Education Policy, Planning and Administration, 1(1), pp. 61-82.

[5] Garrison, D. R., Kanuka, H. Blended learning: Uncovering its transformative potential in higher education. 20.02.2015. [Online]. Available:

http://cecs.anu.edu.au/files/flu_presentation/blended_learning/data /resources/Garrison_2004_The-Internet-and-Higher-Education.pdf

[6] Gosper M., Green D., McNeill M., Phillips R.A., Preston G., Woo K.. (2011). Final Report: The Impact of Web-Based Lecture Technologies on Current and Future Practices in Learning and Teaching. Australian Learning and Teaching Council, Sydney. 11 p.

[7] Heather S., Horn Michael B, Classifying K-12 Blended Learning, Innosight Institute, USA, 2012. 22 p.

[8] Sharma P., Blended Learning: Books for teachers. 22.02.2015. [Online]. Available: http://files.eric.ed.gov/fulltext/ED535180.pdf

[9] Bersin J. (2004). The Blended Learning Book: Best Practices, Proven Methodologies, and Lessons Learned. 319 p.

\section{AUTHORS}

T. Yu. Aikina is with the National Research Tomsk Polytechnic University, Tomsk, Russia (e-mail: aikina@tpu.ru)

O. V. Sumtsova is with the National Research Tomsk Polytechnic University, Tomsk, Russia (e-mail: olgasumtsova0205@mail.ru)

D. I. Pavlov is with the National Research Tomsk Polytechnic University, Tomsk, Russia (e-mail: dipavlov@tpu.ru)

Manuscript received 23 March 2015. Published as resubmitted by the authors 11 May 2015. 